\title{
PRAKTEK PEMBAYARAN HUTANG DENGAN BEKERJA PRESPEKTIF FIQH MUAMALAH \\ (Studi Kasus di Jorong Malintang Nagari Lawang Mandahiling Kecamatan Salimpaung Kabupaten Tanah Datar)
}

\author{
Putri Handayani ${ }^{1}$, Sulastri Caniago ${ }^{2}$ \\ ${ }^{1}$ Institut Agama Islam Negeri Batusangkar \\ e-mail: handayanip745@gmail.com \\ 2Institut Agama Islam Negeri Batusangkar \\ e-mail: sulastricaniago@iainbatusangkar.ac.id
}

\begin{abstract}
This study aims to explain the practice of paying debts by working in terms of fiqh muamalah in Jorong Malintang Nagari Lawang Mandabiling, Salimpaung District, Tanah Datar Regency. This research is a field research. The data sources consist of primary data sources, namely 7 people who owe, 7 people who give debts and 1 scholar, while secondary data sources are documentation and books and scientific works related to accounts payable. Data collection techniques that the author uses are interviews and documentation. The data analysis technique that the author uses is descriptive qualitative analysis. This study found that the implementation of debt payments by working carried out by the community in Jorong Malintang Nagari Lawang Mandahiling, Sallimpanng District, Tanah Datar Regency, namely debt and money receivables which was only done verbally without any written evidence. If it is due, but the borrower is unable to pay it and the payment is made by working in the person's field with his wages taken in exchange for the debt. The execution of debts paid by work is included in usury where the debtor takes the excess wages for working money when paying his debts.
\end{abstract}

Keywords: Hutang Piutang, Bekerja, Fiqh Muamalah

\section{PENDAHULUAN}

Konsep utang piutang yang ada dalam Islam pada dasarnya adalah untuk memberikan kemudahan bagi orang yang sedang kesusahan dan ada yang membutuhkan. utang piutang merupakan transaksi yang sering dilakukan oleh manusia. Menolong seseorang karena kesulitan hendaknya diperhatikan bahwa memberi pertolongan itu tidak mencari keuntungan yang besar tetapi hanyasekedar mengurangi atau menghilangkan beban atas kebutuhan yang sedang seseorang butuhkan, janganlah mencari keuntungan yang batil dalam setiap perniagaan (Ya'kub, 1995: 242).

Transaksi utang piutang ini mempunyai arti dalam kehidupan agar saling memberi pertolongan dan mempunyai nilai kebaikan yang berpahala di sisi Allah SWT. Rasulullah SAW juga menyuruh orang-orang yang mampu untuk memberikan pertolongan kepada yang mendapat kesulitan dalam bentuk utang piutang yang tidak ada unsur riba dan kezaliman di dalamnya.

Dalam melakukan transaksi utang piutang ada rukun dan syarat yang harus dipenuhi. Di dalam praktenya ditemukan transaksi yang berbeda dengan prinsip muamalah sebagaimana penulis temukan secara langsung terhadap salah satubentuk utang piutang yang diganti dengan bekerja yang terjadi di masyarakat di Jorong Malintang Nagari Lawang Mandahiling Kecamatan Salimpaung Kabupaten Tanah Datar. Berdasarkan 
penelitian awal penulis di Jorong Malintang Nagari Lawang Mandahiling Kecamatan Salimpaung Kabupaten Tanah Datar terjadi sebuah transaksi utang piutang uang dalam bentuk pengembalian uang tersebut diganti dengan bekerja. Karena Masyarakat Jorong Malintang Nagari Lawang Mandahiling Kecamatan Salimpaung Kabupaten Tanah Datar mayoritas mata pencariannya bertani.

Utang piutang dilatarbelakangi oleh desakan ekonomi, baik itu untuk memenuhi kebutuhan sehari-hari dan kebutuhan yang lainnya. Hutang piutang yang penulis teliti ini yang mana mereka melakukannya dengan kemaun sendiri. Utang piutang yang masyarakat lakukan di Jorong Malintang Nagari Lawang Mandahiling Kecamatan Salimpaung Kabupaten Tanah Datar yaitu pinjaman uang diganti dengan bekerja maka dengan cara berutang seperti ini yang dapat dilakukan untuk memenuhi kebutuhan baik itu untuk memenuhi kebutuhan hidupnya, salah satu jalan yang ditempuh masyarakat adalah dengan cara berutang. (BR, masyarakat Jorong Malintang pada tanggal 25 Oktober 2019, jam 16.00 WIB)

Berdasarkan penelitian yang penulis lakukan utang piutang yang diganti dengan bekerja hal ini dilakukan karena ketidaksanggupan masyarakat untuk membayar utangnya tersebut dengan uang atau dengan benda maka ia meminta kepada peminjam uang untuk membayarnya dengan bekerja. Dan berdasarkan realita di lapangan yang terjadi di Jorong Malintang Nagari Lawang Mandahiling Kecamatan Salimpaung Kabupaten Tanah Datar dimana seorang peminjam meminjam uang kepada seseorang namun ketika peminjaman jatuh waktu yang ditetapkan untuk mengembalikan uang, pinjaman tidak dapat mengembalikannya dan ia meminta kepada pemberiutang untuk memperkerjakannya sebagai buruh. Padahal dalam Islam utang itu memberikan sesuatu kepada orang lain yang membutuhkan baik berupa uang maupun benda dalam jumlah tertentu dengan perjanjian yang telah disepakati bersama, dimana orang yang diberi uang tersebut harus mengembalikan uang atau benda yang diutangnya dengan jumlah yang sama tidak kurang atau lebih pada waktu yang ditentukan.

Berdasarkan kejadian tersebut penulis menemui di lapangan yaitu di Jorong Malintang Nagari Lawang Mandahiling Kecamatan Salimpaung Kabupaten Tanah Datar, terdapat 15 orang yang melakukan utang piutang yang diganti dengan bekerja dan 6 orang yang memberikan pinjaman uang. Nama orang yang 15 tersebut yaitu : BR, PI, PJ, BE, BN, BR, PM, BL, PH, PZ, BR, BP, BO, PK, PA, dan 6 orang yang memberikan pinjaman, yaitu: B, Q, Y, P, X, W. Dan setelah itu orang yang meminjam tidak mampu membayar utangnya kepada orang yang memberikan pinjaman tersebut. Maka, dari itu orang yang meminjam meminta kepada orang yang memberi utang untuk bekerja melunasi utangnya, karena ketidaksanggupan untuk membayarnya.

Utang yang dibayar dengan cara bekerja, dimana tidak adanya kesepakatan/perjanjian di awal pas meminjam uang tersebut untuk mengganti utang dengan bekerja, seperti jenis pekerjaannya yaitu sebagai petani. Dalam hal ini orang tersebut diminta untuk bekerja diladang, seperti disuruh untuk memanentanaman yang ada di ladang dan membersihkannya serta menggarapnya. Dengan waktu dan hari yang berbeda-beda, waktu bekerjanya dari jam 08.00 Wib sampai 17.30 Wib diluar makan. Dari penjelasan data di atas terdapat selisih antarautang dengan bayarannya. 


\section{METODE PENELITIAN}

Penelitian ini adalah penelitian lapangan yang penulis lakukan di Jorong Malintang Nagari Lawang Mandahiling Kecamatan Salimpaung Kabupaten Tanah Datar. Sumber data primer yaitu hasil wawancara dengan orang yang melakukan pelaksanaan praktek pembayaran utang dengan bekerja yaitu 7 orang yang berutang, 7 orang yang memberikan utang, dan 1 orang alim ulama yang berada di Nagari Lawang mandahiling. Sedangkan sumber data sekunder adalah sumber data yang diperoleh melalui sejumlah buku, jurnal, dan bacaan lainnya yang ada hubungannya dengan judul penelitian ini. Teknik pengumpulan data dilakukan dengan wawancara disusun secara sistematis dan lengkap untuk mengumpulkan data yang dicari Dokumentasi. Teknik analisis dilakukan dengan cara penafsiran penelitian terhadap data dan pemecahan masalah yang akan diolah. Data yang diperoleh dari penelitian lapangan akan dianalisis secara deskriptif analisis, yaitu penelitian yang berusaha mendeskripsikan suatu gejala, peristiwa, kejadian yang terjadi saat sekarang. Teknik penjamin keabsahan data adalah Trigulasi.

\section{HASIL DAN PEMBAHASAN}

\section{A.Pelaksanaan Pembayaran Utang Dengan Bekerja Yang Dilakukan Oleh Masyarakat Di Jorong Malintang Nagari Lawang MandahilingKecamatan Salimpaung Kabupaten Tanah Datar.}

Adapun fenomena utang piutang yang terjadi di Jorong Malintang Nagari Lawang Mandahiling Kecamatan Salimpaung Kecamatan Tanah Datar, dimana dalam transaksinya dilakukan oleh masyarakat dengan pemilik kebun. Dalam hal ini masyarakat meminjam uang ke pemilik kebun dengan waktu pembayarannya/melunasi telah ditentukan sebelumnya, namun masyarakat tidak sanggup untuk melunasinya jika sudah masuk jatuh waktu temponya. Oleh karenanya masyarakat memilih bekerja diladang/kebun yang memberikan pinjaman tersebut.

Salah satu masyarakat yang berhutang yaitu seorang bernama ibu BR. Ibu ini bekerja sebagai petani. Pada waktu itu tepatnya jam 09.00 pagi ibu BR datang kerumah bapak B, maksud kedatangan ibu BR tersebut adalah untuk bisa meminjam uang/berutang ke bapak B. ( wawancara pribadi dengani bu BR lewat via telfon pada tanggal 01 Mei 2020). Sementara bapak B (pemberi pinjaman) mengatakan bahwa ibu BR datang kerumahnya untuk bisa meminjamkan uang kepadanya, dengan jumlah uang yang dipinjam sesuai dengan kehendak ibu BR, dengan memberi waktu 1 minggu untuk bisa melunasinya kembali. Ibu BR setuju dengan hal tersebut, saya hanya memberikan pinnjaman karena ibu BR nampaknya membutuhkan uang itu sekali dan ada hal mendesak yang harus dia urus (Wawancara pribadi dengan bapak B ( pemberi utang) melalui via telfon pada tanggal 01 Mei 2020)

Alasan ibu BR meminjam uang waktu itu adalah untuk kebutuhan sekolah anaknya dan kebutuhan hidupnya sehari-hari. Pada waktu itu kata bapak B memberi waktu 1 minggu paling lama ke ibu BR untuk bisa mengganti uang tersebut. Tetapi setelah waktu 1 minggu ternyata ibu BR belum sanggup untuk membayar utangnya tersebut dan meminta ke bapak B tersebut untuk bekerja diladangnya selama 1 minggu lebih ( 8 hari) dan upahnya tersebut di anggap sebagai pengganti utang ibu BR. Jenis pekerjaan yang dilakukan ibu BR 
tersebut adalah memanen hasil kebun dan menggrapnya serta membersihkannya, yang dimulai dari jam 07.30 wib- 17.30 wib diluar makan.

Kata bapak B ( pemberi utang) alasan ibu BR bekerja diladangnya untuk melunasi utangnya kerena ibu BR belum sanggup untuk membayar utang tersebut, jadi itu adalah kemauan dari ibu BR sendiri, saya tidak dapat berkata apa-apa lagi, karena saya juga butuh uang untuk mengelola ladang saya, jadi sebagai gantinya ibu BR bekerja diladang saya.( wawancara pribadi dengan bapak B pada tanggal 01 Mei 2020, via telfon)

Pada saat itu upah standar petani di jorong tersebut sebesar Rp. 75.000/hari. Sedangkan ibu BR bekerja selama 8 hari, dimana jumlah total upah uang yang harus diterima ibu BR adalah sebanyak Rp. 600.000, sedangkan utang ibu BR hanya Rp. 500.000, dalam hal ini terdapat ketidakseimbangan antara upah dan utang yang harus dibayarkan ibu BR ke pemilik kebun tersebut. Terdapat kelebihan uang yang di ambil oleh pemilik kebun tersebut sebanyak Rp. 100.000.

Sementara penulis juga melakukan wawancara kepada bapak PI selaku masyarakat di Jorong Malintang tersebut yang bekerja sebagai petani juga. Beliau mengemukakan alasannya untuk meminjam uang ke bapak $Q$ adalah untuk membayar arisan dan untuk memenuhi kebutuhan hidupnya sehari-hari. (wawancara pribadi dengan bapak PI, pada tanggal 01 Mei 2020, via telfon) Bapak PI meminjam uang sebanyak Rp. 250.000 kepada bapak Q, dan akan berjanji waktu 1 minggu untuk melunasinya. Tetapi setalah 1 minggu bapak PI belum mempunyai uang untuk mengganti utang tersebut, tanpa berpikir panjang bapak PI juga meminta bekerja di ladang orang tersebut untuk mengganti utangnya tadi.

Selanjutnya Penulis juga melakukan wawancara dengan bapak Q ( yang memberikan pinjaman). Bapak PI diminta bekerja selama 4 hari oleh bapak $Q$ di ladangnya, jenis pekerjaannya juga sama halnnya dengan ibu BR. Dalam hal ini juga terdapat selisih antara utang dengan upah yang mestinya akan dibayar oleh bapak PI tersebut bapak Q. Dimana bapak Q tersebut mengambil kelebihan upah bapak PI sebanyak Rp. 50.000. Begitulah kebiasaan yang dilakukan masyarakat di Jorong Malintang Nagari Lawang Mandahiling Kecamatan Salimpaung Kabupaten Tanah Datar.

Hal senada juga disampaikan oleh ibu BE masyarakat Jorong Malintang Nagari Lawang Mandahiling. Ibu BE meminjam uang ke bapak P. (wawancara pribadi dengan ibu BE, pada tangal 06 Mei 2020, Via telfon) Dalam hal tersebut ibu BE meminta waktu 1 minggu untuk membayar utangnya ke bapak $\mathrm{P}$, dan bapak $\mathrm{P}$ mentujuinya, tetapi telah lewat satu minggu ibu BE belum juga melunasi utangnya.

Penulis juga melakukan wawancara ke bapak $\mathrm{P}$ ( pemberi utang) kata bapak $\mathrm{P}$, setiap masyarakat yang meminjam uang kepadanya kebanyakan menggantinya dengan bekerja, karena ketidaksanggupan masyarakat tersebut, alasan bapak P mau menggantinya dengan bekerja adalah untuk menghindari hal-hal buruk yang akan terjadi, karena utang piutang ini kita nantinya bisa bertengkar dan merusak tali silaturahmi antara dirinya dengan masyarakat, dan hal ini sudah menjadi kebiasaan masyarakat mengganti uang dengan bekerja di Jorong Malintang Nagari Lawang Mandahiling Kecamatan Salimpuang Kabupaten Tanah Datar. ( wawancara pribadi dengan pemberi utang melalui via telfon pada tanggal 06 Mei 2020).

Sementara penulis juga mewawancarai bapak BN, yaitu masyarakat Jorong Malintang Nagari Lawang Mandahiling, beliau kesehariannya bekerja sebagai petani juga. Suatu hari 
bapak BN sangat membutuhkan uang untuk membelikan laptop untuk anaknya yang kuliyah di Universitas luar Sumatera Barat, karena desakan tersebut bapak BN meminjam uang ke ibu X sebanyak Rp. 600.000 saja, karena uang tersebut hanya untuk tambahan saja. Dan bapak BN berjanji untuk melunasi utang tersebut dalam 1 minggu. Tapi setelah lewat 1 minggu bapak BN belum sanggup untuk membayarnya, dan ibu $\mathrm{X}$ juga membutuhkan uang tersebut, tanpa berpikir panjang bapak BN memilih untuk bekerja diladang ibu $X$ dan upah tersebut sebagai ganti utangnya tadi. Bapak BN bekerja selama 10 hari diladang tersebut, walaupun merasa keberatan, tapi bapak BN hanya sanggup untuk membayarnya dengan cara bekerja. (Wawancara dengan bapak BN, pada tanggal 21 Juni 2020)

Dan penulis juga melakukan wawancara kepada ibu PM, waktu itu ibu PM meminjam uang kepada bapak $C$, untuk acara sunatan anaknya yang berumur 7 tahun, pada waktu itu PM hanya meminjam uang sebanyak Rp. 500.000 saja, dalam waktu 1 minggu untuk bisa membayarnya lagi. Karena ibu PM belum sanggup untuk membayarnya dan ibu PM meminta bekerja diladang bapak $C$ tersebut selama 8 hari. Dan upahnya itu di anggap sebagai ganti utang ibu PM.

Hal senada juga disampaikan oleh ibu BL, masyarakat Jorong Malintang Nagari Lawang Mandahiling, ibu ini bekerja sebagai petani dan berjualan kepasar kesehariannya, waktu itu ibu BL meminjam uang ke ibu D untuk tambahan modal usaha suaminya, ibu BL meminjam uang sebanyak Rp. 600.000 saja pada waktu itu. Ibu BL berjanji dalam waktu 1 minggu untuk melunasinya, dan setelah lewat waktu 1 minggu ibu BL belum sanggup untuk membayarnya, dan tanpa berpikir panjang ibu BL bersedia saja untuk bekerja diladang ibu D dan upahnya itu sebagai ganti utang ibu BL, lama bekerjanya yaitu selama 10 hari. (Wawancara dengan ibu BL, pada tanggal 21 Juni 2020)

Selanjutnya penulis juga melakukan wawancara dengan pemuka agama yang berada di Jorong Malintang Nagari Lawang Mandahiling, beberapa keterangan yang diproleh dari Suhat (alim ulama) yang akrab dipanggil pak Siwaik, beliau alim ulama yang berada di Nagari Lawang Mandahiling. Beliau mengatakan bahwa pelaksanaan utang piutang uang ini banyak terjadi di Jorong Malintang Nagari Lawang Mandahiling Kecamatan Salimpaung Kabupaten Tanah Datar. Seperti utang yang dibayar dengan bekerja, hal tersebut boleh saja dilakukan jika ada kesepakatan antara kedua belah pihak, tetapi dalam hal ini adanya kerugian yang ditanggung oleh si peminjam kepada yang memberikan utang tersebut. Dimana tidak seimbangnya antara upah yang harus dibayarkan kepada orang yang sudah bekerja diladang dengan potongan upah tersbut diambil untuk melunasi utangnya.

Karena masyarakat jarang sekali mengikuti pengajian ataupun wirid yang menjelaskan tentang muamalah. Karena sehariannya sibuk bekerja dan malam harinya kelelahan sehingga tidak bisa untuk hadir mengikuti pengajian, yang mana kebiasaan wirid dan pengajian dilakukan pada malam hari sehingga kurang mengetahui bagaimana pelaksanaan utang piutang uang yang dibolehkan dalam ajaran Islam. Masyarakat melakukan pelaksanaan muamalah dengan jalan sendiri tanpa adanya aturan yang menuntun, yang penting bagi mereka adalah bisa bertahan hidup. Sedangkan nilai agama dalam sendi kehidupan masyarakat kurang teraplikasi. Alim ulama ini memberikan keterangan menyatakan bahwa utang piutang ini bahwasanya tidak boleh dilakukan kerana akan mendatangkan mudharat oleh banyak orang yang mengakibatkan ekonomi 
masyarakat akan menurun dan menguntungkan bagi orang yang memberikan utang tersebut. Manfaat yang dirasakan oleh si peminjam adalah lebih mudah didapatkan uang dikarenakan hanya kebutuhan yang mendesak.( wawancara pribadi dengan alim ulama yang berada di Jorong Malintang Nagari Lawang Mandahiling, 01 Mei 2020, via telfon).

Selain merasa tertolong dengan utang piutang yang dilakukan oleh masyarakat di Jorong Malintang Nagari Lawang Mandahiling tesebut, tanpa disadari adanya salah satu pihak yang dirugikan karena tidak seimbangnya utang yang diganti dengan cara bekerja. Sesuai dengan wawancara penulis dengan masyarakat, bahwa mereka mengatakan : "saya belum ada uang untuk membayar utang tersebut, sebagai gantinya saya bekerja diladang bapak"

Dalam transaksi utang piutang antara masyarakat dengan si pemberi pinjaman di Jorong Malintang Nagari Lawang Mandahiling dilakukan dengan saling kepercayaan atau secara lisan tanpa adanya alat bakti tertulis yang dapat menajadi bukti transaksi utang piutang.

Dari penelitian yang penulis lakukan di Jorong Malintang Nagari Lawang Mandahiling Kecamatan Salimpaung Kabupaten Tanah Datar melakukan utang piutang antara masyarakat dengan pemberi utang dengan mengganti utang tersebut dengan bekerja. Alasan masyarakat meminjam uang tersebut adalah untuk memenuhi kebutuhan hidupnya dan untuk biaya sekolah anak-anaknya. Alasan sipemberi utang menerima ganti uang dengan bekerja adalah untuk tidak terjadi hal-hal buruk yang tidak di inginkan, seperti pertengakaran dan merusak tali silaturahmi, karena masyarakat hanya sanggup membayarnya dengan bekerja.

\section{B. Pandangan Fiqh Muamalah Terhadap Utang Dibayar dengan Bekerja Di Jorong Malintang Nagari Lawang Mandahiling Kecamatan Salimpaung Kabupaten Tanah Datar.}

Utang piutang atau qardh dikatakan sah apabila memenuhi rukun dan syarat qardh, yaitu:

1. Orang yang berakad („,Aqid)

Pihak yang terlibat dalam transaksi adalah orang yang cakap dalam bertindak hukum terhadap harta dan berbuat kebajikan yaitu: telah dewasa, berakal sehat dan berbuat sendiri tanpa paksaan (Gufraon, 2000: 50) sedangkan menurut Abdurrahman al-Jaziri, dalam hal utang piutang harus ada dua pihak yang melakukan akad yaitu orang yang berutang dan pemberi utang, kedua pihak ini bisa juga disebut sebagai subjek akad(Rasyid, 2005: 57).

Menurut ulama fiqih setiap subjek akad harus memenuhi syarat-syarat sebagai berikut:

a. Berakal

Tidak sah akad (dalam hal ini utang piutang) yang dilakukan oleh orang yang tidak waras (gila)

b. Atas Kehendak sendiri

Maksudnya akad yang dilakukan oleh para pihak dalam utang piutang itu harus atas kehendak sendiri tanpa ada paksaan atau tekanan dari pihak manapun.Kehendak sendiri atas persetujuan kedua belah pihak yang merupakan unsur penting dalam akad utang piutang. 


\section{c. Baligh}

Tidak sah akad utang piutang yang dilakukan oleh orang yang belum baligh (anakanak) karena seorang anak belum cakap melakukan tindakan hukum.

d. Tidak di bawah perwalian

Dalam setiap hukum Islam tidak semua orang dipandang cakap melakukan tindakan hukum walaupun dari segi umur telah dewasa, seperti yang dikemukakan oleh Ahmad Azhar Basjir menyatakan bahwa dalam melakukan akad orang yang di pandang tidak cakap melakukan akad maka akad tersebut tidak ada nilainya. (Syarifuddin, 2010: 224)

\section{Objek utang Piutang}

Menurut Khairuman Pasaribu mengemukakan bahwa barang yang diutangkan disyaratkan harus benda yang dapat diukur atau diketahui jumlahnya atau nilainya. Agar pada waktu pembayaran tidak menyulitkan sebab dalam pengembaliannya nilai barang yang akan dibayarkan sama dengan nilai barang yang diterima. (Khairuman, 1994: 137)

Ulama Hanafiyah mengatakan akad utang piutang hanya berlaku pada harta benda al-Misliyat yakni harta benda yang banyak padanya, yang lazim dihitung dalam timbangan, takaran dan satuan, sedangkan harta benda al-Qimiyat tidak sah dijadikan objek utang seperti hasil seni, rumah, tanah, hewan dan lain-lain. Ulama Malikiyah, Syafiiyah dan Hanabilah mengemukakan harta benda yang boleh diberlakukan atasnya akad salam, maka boleh diberlakukan atasnya utang piutang baik berupa harta benda al-Misliyat (harta benda yang jenisnya dapat diperoleh dipasar) maupun al-Qimiyat (harta benda yang jenisnya sulit didapatkan di pasar). (Hamzah, 1992: 190)

Setiap utang harus diabayar sesuai dengan nilai yang dipinjam sebelumnya. Melebihkan bayaran dari sejumlah pinjaman diperbolehkan, asalkan saja kelebihan itu merupakan kemauan dari yang berutang semata. Hal ini menjadi nilai kebaikan bagi yang membayar utang, utang piutang harus disertakan dengan niat yang baik dari peminjam maupun dari yang meminjamkan.

Sayyid Sabiq menegaskan bahwa boleh memberikan utang berupa pakaian dan hewan karena Rasulullah pernah mengutangkan hewan (unta) kepada seseorang. Dapat dipahami bahwa mengenai barang atau benda yang diutangkan itu boleh berupa benda atau barang yang bisa ditukar, ditimbang maupun benda yang tidak dapat ditimbang karena dapat mempermudah kita dalam membayar utang yang penting pada saat pengembalian hendaklah dengan yang semisal (sama). (Sabiq, 2012: 237)

3. Sighat utang Piutang

Kalimat akad dapat dilihat dari contoh berikut: yang memberi piutang berkata "Aku utangkan ini kepada engkau". Kemudian dijawab oleh orang yang berutang "Aku mengaku berutang kepada engkau" dan aku berjanji akan membayarnya pada hari itu atau bulan itu". Namun dalam kehidupan sehari-hari orang sering menggunakan kalimat seperti di atas untuk transaksi pinjam meminjam dan orang juga sering menyamakanantara utang dengan pinjaman. berikut:

Ketentuan dan adab utang piutang yang di anjurkan dalam Islam yaitu sebagai a. Utang piutang harus ditulis dan dipersaksikan.

b. Pemberi utang atau pinjaman tidak boleh mengambil keuntungandan manfaat dari 
orang-orang yang berutang.

c. Melunasi utang dengan cara baik.

d. Berutang dengan niat yang baik dan akan melunasinya.

e. Tidak berutang kecuali dalam keadaan darurat atau mendesak.

f. Jika terjadi keterlambatan pembayaran karena kesulitan keuangan, hendaklah orang yang berutang memberitahukan kepada orang yang memberikan pinjaman.

g. Bersegera melunasi utang (Elimartati, 2010: 164)

h. Memberikan penangguhan waktu kepada orang yang sedang kesulitan dalam melunasi utangnya setelah jatuh tempo.

Dalam pelaksanaan akad utang piutang yang terjadi Di Jorong Malintang Nagari Lawang Maandahiling Kecamatan SalimpaungKabupaten Tanah Datar telah memenuhi rukun dan syaratnya, dimanaadanya sipeminjam dan pemberi utang, yang objeknya adalah uang. Dalam Islam utang piutang itu bersifat tolong menolong antar sesama,dimana masyarakat yang lagi kesusahan wajiblah untuk kita menolongnya.

Akad utang piutang itu sendiri merupakan kebajikan yang telah diisyaratkan dalam Islam. Hukumnya Mubah atau Boleh. (Syarifuddin, 2010: 222). Tujuan diperbolehkannya utang piutang itu adalah untuk memberikan kemudahan bagi umat manusia, manusia itu ada yang berkecukupan dan ada yang berkekurangan. Orang yang berkurangan memanfaatkan utang dari pihak yang berkecukupan dimana ia bisa menolong sesama umat.

Syarat keabsahan akad ini dibedakan menjadi dua macam, yaitu syarat-syarat keabsahan umum yang berlaku terhadap semua akad atau paling tidak berlaku terhadap kebanyakan akad, dan syarat-syarat keabsahan khusus yang berlaku bagi masing-masing aneka akad khusus(Anwar, 2007: 99). Adapun syarat keabsahan umum yang harus dipenuhi dalam berbagai macam akad adalah sebagai berikut:

1) Kedua orang yang melakukan akad cakap (ahli). Tidak sah akad orangyang tidak cakap bertindak seperti orang gila, orang yang beradadibawah pengampuan (mahjur) karena boros dan lainnya.

2) Yang dijadikan objek akad dapat menerima hukumnya.

3) Akad itu diizinkan oleh syara' dilakukan oleh orang yang mempunyai hak melakukannya walaupun dia bukan aqid yang memiliki barang.

4) Janganlah akad itu akad yang dilarang oleh syara'.

5) Akad dapat memberikan faidah sehingga tidaklah sah bila rahn dianggap sebagai imbalan amanah.

6) Ijab itu berjalan terus, tidak disebut sebelum terjadi qabul, maka bila orang yang berhijab menarik kembali ijabnya sebelum qabul, maka batallah hijabnya.

7) Ijab dan qabul mestilah bersambung sehingga bila seseorang yang berijab sudah berpisah sebelum adanya qabul, maka ijab tersebut menjadi batal (Suhendi, 2010: 50).

Sementara untuk syarat akad khusus bisa juga disebut syarat idhafi (tambahan) yang harus ada disamping syarat-syarat yang umum seperti syarat adanya saksi dalam pernikahan (Suhendi, 2010: 99). Secara umum ada empat sebab yang menjadikan fasidnya suatu akad meskipun telah memenuhi rukun dan syarat terbentuknya akad, yaitu:

a) Penyerahan yang menimbulkan kerugian.

b) Gharar. 
c) Syarat-syarat fasid.

d) Riba.

Bebas dari keempat faktor ini merupakan syarat keabsahan akad. Akad yang telah memenuhi rukunnya, syarat terbentuknya dan syarat keabsahannya dinyatakan sebagai akad yang sah. Apabila syarat keabsahan yang empat ini tidak terpenuhi, meskinya rukun dan syarat terbentuknya akad telah dipenuhi, akad tidak sah. Akad ini disebut dengan akad fasid (Anwar, 2007: 100-101). Mayoritas ahli hukum islam, Maliki, Syafi'i dan Hambali tidak membedakan antara akad batil dan akad fasid. Keduanya sama-sama merupakan akad yang tidak sah, karena tidakmenimbulkan akibat hukum apapun. Tidak dibedakan kerusakan akadyang terjadi pada dasarnya (rukun dan syarat pembentukannya) dan pada sifatnya (syarat keabsahannya). Bila salah satu keduannya rusak atau tidak terpenuhi, maka akad itu fasid atau batal, sedangkan fasid atau batal itu sama, yaitu sama-sama tidak sah dan tidak menimbulkan akibat hukum. Ketidaksahannya disebabkan oleh karena akad tersebut tidak memenuhi ketentuan undang-undang syara' (Anwar, 2007: 249).

Hal ini juga dijelaskan oleh 4 imam imam mazhab, yaitu:

1. Hanafiah memakruhkan seseorang yang berutang sesuatu kepada orang lain untuk memperoleh manfaat tertentu bila itu disyaratkan dalam akad. Misalnya seseorang mengutangkan gandum yang kotorkemudian mensyaratkan agar orang tersebut untuk membayarnya dengan gandum yang bersih.

2. Malikiyah berpendapat bahwa haram dalam utang piutang menentukan syarat untuk mendapat manfaat, misalnya mensyaratkan membayar utang dengan hewan yang sehat padahal hewan yang diutangkan lemah.

3. Hanabilah menyebutkan bahwa dalam utang piutang tidak boleh mensyaratkan sesuatu untuk mendapat manfaat tambahan bagi yang mengutangkan atau dengan syarat memberikan hadiah dan lain sebagainya.

4. Sedangkan syafi'I memberikan beberapa ketentuan dalam hal utang piutang bersyarat ini, yaitu:

a) Apabila syarat yang diberikan itu bertujuan untuk mengambil manfaat untuk kepentingan orang yang berpiutang, maka dalam halini akad utangnya rusak dan hukum utangnya tidak sah atau haram.

b) Apabila syarat yang diberikan itu bertujuan untuk mengambil manfaat untuk kepentingan orang yang berutang, maka dalam hal ini syaratnya rusak, sedang akadnya sah.

c) Apabila syarat yang diberikan hanya digunakan untuk kepercayaan, seperti disyaratkan bagi pihak yang berutang untuk memberikan sertifikat tanah sebagai jaminan utangnya kepada orang yang berpiutang, maka yang demikian itu dapat dibenarkan menurut hukum islam.

Dari penelitian yang penulis lakukan utang piutang yang terjadi diJorong Malintang Nagari Lawang Mandhiling Kecamatan Salimpaung Kabupaten Tanah Datar bahwa dalam melunasinya, masyarakatmembayarnya dengan bekerja. Dalam Islam sudah dijelaskan bahwa jika utang uang juga harus dibayar dengan uang dan jika utang emas juga dibayar dengan emas juga, serta jika utang barang harus dibayar dengan barang juga.

Boleh bagi si pengutang untuk membayar utang emas dengan menggunakan uang dengan syarat. Kesepakatan membayar dengan uang ini baru terjadi saat pelunasan. 
Kemudian uang yang digunakan untuk melunasi harus sesuai dengan harga emas pada saat pelunasan. Bukan harga emas pada saat akad utang. Disebutkan dalam salah satu fatwa : "Boleh bagi si pengutang untuk melunasi utangnya dengan barang lain yang tidak sesuai dengan jenis atau macam barang yang ia pinjam seperti emas untuk melunasi utang berupa uang, akan tetapi dengan dua syarat:

1) Tidak ada kesepakatan sebelumnya terhadap bentuk pelunasan model seperti ini (karena memiliki kesamaan dari sisi penyebab riba). Akan tetapi kesepakatan ini baru ditawarkan pada saat pelunasan utang. Karena kesepakatan untuk melunasi utang berupa uang dengan emas dengan tanpa ada aksi pembayaran langsung, hal itu menjerumuskan ke dalam praktek riba nasyi"ah.

2) Yang menjadi patokan adalah harga emas pada saat perlunasan bukan harga emas pada saat utang ( Fatwa Darul Ifta Yordania No.2032).

Jika syarat ini terpenuhi maka tidak mengapa penanya membayar utang emas dengan menggunakan uang. Dan jika tidak tahu berapa gram jumlah emas yang dipinjam maka diusahakan untuk meminta keterangan saksi_yang dulu disepakati oleh kedua belah pihak. Tetapi hal lain yang terjadi dilapangan, penulis melihat kejadian dimasyarakat di Jorong Malintang Nagari Lawang MandahilingKecamatan Salimpaung Kabupaten Tanah Datar bahwa utang uangnya diganti dengan bekerja. Cara masyarakat melakukannya yaitu bekerja di ladang orang yang memberikan pinjaman tersebut, dengan upahnya diambil sebagai ganti utangnya. Dimana pada saat itu upah perhari bekerja di ladang adalah sebanyak Rp.75.000, misalnya masyarakat mempunyai utang sebanyak Rp. 500.000 dan pada saat itu masyarakat disuruh bekerja selama 8 hari di ladang, jadi upah yang harus diterima masyarakat adalah sebanyak Rp.600.000, disini adanya perselisihan saat melunasinya utangnya, selisihnya yaitu Rp.100.000. Dan si pemilik ladang mengambil semua upah masyarakat yang bekerja selama 8 hari tersebut.

Sementara itu dari segi waktu pelaksanaan utang piutang uang di Jorong Malintang Nagari Lawang Mandahiling Kecamatan Salimpaung Kabupaten Tanah Datar telah memenuhi akadnya, yaitu jika sudah masuk jatuh tempo si peminjam harus membayarnya, tapi hal tersebut tidak terpenuhi karena si peminjam belum sanggup untuk membayar utang tersebut. Pihak yang berpiutang juga telah memberi kelonggaran atau kelapangan bagi pihak yang belum mampu membayar utangnya.

Dalam melakukan utang piutang umat Islam dituntut memberikan kemudahan kepada orang yang mengalami kesulitan bukan sebaliknya. Dengan memberikan kemudahan kepada orang lain, Allah SWT telah menjanjikan terbebas dari sekian banyak kesusahan dihari kiamat nanti. Selain merasa tertolong dengan pinjaman tersebut, hendaknya orang itu memberi tenggang waktu pada masyarakat utuk melunasi utangnya. Memberi tenggang waktu terhadap orang yang kesulitan adalahwajib. Selanjutnya jika ingin membebaskan utangnya, maka ini hukumnya sunnah (dianjurkan). Orang yang berhati baik seperti inilah (dengan membebaskan sebagian atau seluruh utang) yang akan mendapatkan kebaikan dan pahala yang melimpah.

Dalam Islam utang itu boleh saja dibayar dengan dengan bekerja, dengan cara upahnya itu dibayar dulu ke masyarakat, dan nanti masyarakatbaru membayar utangnya dengan upah uang yang diberikan tadi, supaya tidak ada kelebihan uang yang diambil oleh si pemberi utang tersebut. Tetapi hal lain yang terjadi di masyarakat di Jorong Malintang 
Nagari Lawang Mandahiling Kecamatan Salimpaung Kabupaten Tanah Datar bahwa upah kerja masyarakat tersebut langsung diambil semuanya, disini adanya kelebihan uang yang diambil oleh pemilik ladang tersebut. Dalam Islam sangat dilarang mengambil kelebihan utang uang saat membayarnya, hal ini sudah termasuk kedalam kategori riba.

Hal ini sangat dilarang, sesuai dengan kaidah fiqh: "semua utang yang menarik manfaat (keuntungan) adalah sebagiandari beberapa macam riba (bunga)". (HR. Baihaqi). Maksud dari kaidah fiqh diatas adalah apabila seseorang mengambil keuntungan dari utang piutang maka ia telah memakan riba yang mana hal ini bertentangan dengan syarat Islam. (Abdul Djamil, 1992:168- 169).

Jenis riba yang terkandung dalam akad atau transaksi utang piutang uang adalah riba qardh yaitu kelebihan yang diambil dalam akad utang piutang. Kelebihan yang terjadi disini adalah berupa upah orang yang sudah bekerja di ambil semuanya oleh si pemberi utang. Sementara itu jika dilihat cara pembayarannya utang piutang uang di Jorong Malintang Nagari Lawang Mandahiling Kecamatan Salimpaung Kabupaten Tanah Datar sudah sesuai dengan kesepakatan para pihak yang berakad.

Kalau dilihat dari penjelasan ayat tersebut jelaslah bahwasanyapelaksanaan utang piutang uang yang terjadi di Jorong Malintang Nagari Lawang Mandahiling Kecamatan Salimpaung Kabupaten Tanah Datar dalam melakukan pembayarannya sudah dilakukan oleh para pihak sesuai dengan perjanjian yang dibuat. Namun dalam melakukan pembayarannya utang disini terdapat kelebihan diluar pinjaman pokok yang mereka pinjam.

Dalam melakukan pinjaman kepada orang lain yang membutuhkan kita dituntut untuk memberikan pinjaman yang ikhlas tanpa mengharapkan apapun. Hal seperti ini tidak sesuai dengan pelaksanaan utang piutang uang yangterjadi di Jorong Malintang Nagari Lawang Mandahiling Kecamatan Salimpaung Kabupaten Tanah Datar, dimana utang tersebut diganti dengan bekerja dan pihak yang memberikan utang tersebut mengambil kelebihan upah seorang(peminjam) yang telah bekerja diladangnya.

Melebihi peminjaman dari sejumlah pinjaman diperbolehkan,asalkan saja kelebihan itu merupakan kemauan dari yang berutang semata. Hal ini menjadi nilai kebaikan yang membayar utang, Rasulullah SAW bersabda: "Sesungguhnya diantara orang yang terbaik dari kamu adalah orang yang sebaik-baiknya dalam membayar utang" (HR. Bukhari dan Muslim). Jika penambahan tersebut dikehendaki oleh orang yang berutang atau telah menjadi perjanjian dalam akad utang piutang, maka tambahanitu tidak halal bagi yang berpiutang untuk mengambilnya (Suhendi, 2010: 96).

Hal ini juga dijelaskan dalam Al-Qur'an surat Ali Imran ayat 130,yang berbunyi: "Hai orang-orang yang beriman, janganlah kamu memakan Riba dengan berlipat ganda dan bertakwalah kamu kepada Allah supaya kamu mendapat keberuntungan". Yang dimaksud Riba di sini ialah Riba nasi'ah. menurut sebagian besar ulama bahwa Riba nasi'ah itu selamanya haram, walaupun tidak berlipat ganda. Riba itu ada dua macam: nasiah dan fadhl. Riba nasiah ialah pembayaran lebih yang disyaratkan oleh orang yang meminjamkan. Riba fadhl ialah penukaran suatu barang dengan barang yang sejenis,tetapi lebih banyak jumlahnya karena orang yang menukarkan mensyaratkan demikian, seperti penukaran emas dengan emas, padi dengan padi, dan sebagainya. Riba yang dimaksud dalam ayat ini Riba nasiah yang berlipat ganda yang umum terjadi dalam masyarakat Arab zaman jahiliyah. 
Allah melarang orang-orang beriman dari berinteraksi dengan riba saat berutang piutang dengan meminta tambahan atas utang pokok, baik itu sedikit maupun banyak. Setiap bentuk transaksi baikjual beli, sewa menyewa, gadai, pinjam meminjam, kerja sama, dan lainnya, boleh dilakukan, baik yang mengandung unsur syarat atau kesepakatan penunjang atau berbentuk budaya yang mendukung terlaksananya muamalah tersebut, kecuali kedua pihak yang bermuamalah itu melakukan muamalahnya terdapat unsur merugikan salah satu pihak (gharar), karena hal itu berarti sudah terdapat dalil (indikator) yang mengharamkan maka muamalah itu tidak boleh (haram). Inilah yang dimaksud sebagai dalil tersebut. (Kasmidin, 2015: 76)

Secara keseluruhan praktek utang piutang uang yang terjadi di Jorong Malintang Nagari Lawang Mandahiling Kecamatan Salimpaung Kabupaten Tanah Datar belum sesuai dengan prinsip-prinsip muamalah yang diajarkan oleh islam yaitu:

1) Pada dasarnya segala bentuk muamalah adalah mubah, kecuali yang ditentukan oleh AlQur'an dan sunnah Rasul.

2) Muamalah dilakukan atas dasar sukarela tanpa adanya unsur paksaan.

3) Muamalah dilakukan atas dasar pertimbangan mendatangkan manfaat dan menghindari mudharat dalam kehidupan masyarakat.

4) Muamalah dilaksanakan dengan memelihara nilai keadilan, menghindari unsur-unsur penganiayaan, unsur-unsur pengambilan kesempatan dalam kesempitan (Basyir, 2000: 15)

Kalau dilihat dari pelaksanaan utang piutang uang secara keseluruhan di Jorong Malintang Nagari Lawang Mandahiling Kecamatan Salimpaung Kabupaten Tanah Datar, belum menerapkan prinsip-prinsip muamalah yang diatur dalam Islam. Karena salah satu pihak hanya mencari keuntungan untuk diri sendiri tanpa memperhatikan pihak lainnya. Hal ini tentu bertentangan dengan prinsip muamalah, dimana dalam bermuamalah harus menghindari mudharat dan mendatangkan manfaatbaik bagi orang lain maupun untuk diri sendiri.

Jadi menurut penulis pelaksanaan utang piutang ini di arahkan kepada sistem yaitu dengan cara yang baik dan benar, tidak dengan cara utang piutang yang akan menimbulkan riba, akan tetapi kegiatan yang dilkukan penulis temukan dilapangan yaitu kegiatan utang piutang yang diganti dengan bekerja, dimana kelebihan upah orang tersebut di ambil semuanya oleh pemilik kebun karena sudah bekerja diladangnya, hal ini tidak seimbang dengan utang yang seharusnya dibayarkan, karena orang tersebut mendapatkan kelebihan dari utang piutang tersebut. Utang piutang ini jikalau pembayaranya dengan bekerja, menurut penulis tidak seimbanglah dengan jerit payah dan tenaga yang dikeluarkan oleh orang yang berutang tersebut. Dalam Islam utang itu boleh saja dibayar dengan bekerja, dengan cara upahnya itu dibayar dulu ke masyarakat, dan nanti masyarakat baru membayar utangnya dengan upah uang yang diberikan tadi, supaya tidak ada kelebihan uang yang diambil oleh sipemberi utang tersebut.

Hukum memberi kelebihan dalam membayar utang dalam Islam yaitu sebagai berikut:

a. Kelebihan yang tidak diperjanjikan.

Apabila kelebihan pembayaran yang dilakukan oleh orang yang berutang tanpa didasarkan pada perjanjian sebelumnya, dan hanya sebagai ucapan terimakasih 
(kebaikan, maka kelebihan tersebut(hukumnya) boleh (halal) bagi orang yang memberi utang.

b. Kelebihan yang diperjanjikan.

Apabila kelebihan pembayaran dilakukan oleh orang yang berutang kepada orang yang memberi utang didasarkan pada perjanjian yang telah disepakati sebelumnya, maka hukumnya tidak boleh, dan haram bagi orang yang memberi utang untuk menerima kelebihan tersebut (Imam Abi Al-Husain Muslim, 2003: 169).

Tambahan dalam utang-piutang (al-qardh) menurut Islam, ada dua macam yaitu sebagaimana berikut ini:

1) Penambahan yang disyaratkan. Demikian ini dilarang berdasarkan ijma". Begitu juga manfaat yang disyaratkan, seperti perkataan: "aku memberi utang kepadamu dengan syarat kamu memberi hak kepadakuuntuk menempati rumahmu," atau syarat manfaat lainnya. Demikian ini termasuk rekayasa terhadap riba.

2) Jika penambahan diberikan ketika membayar utang tanpa syarat, makayang demikian ini boleh dan termasuk pembayaran yang baik berdasarkan hadits yang telah dikemukakan di pasal dasar al-qardh (utang-piutang).

Pelunasan/pembayaran kembali utang wajib dilakukan sesuai isi perjanjian yang telah menjadi kata sepakat kedua belah pihak. Pada saat pelunasan yang wajib dikembalikan hanya sebesar utang yang diterima. Dan karena tidak dibenarkan dalam perjanjian berisikan tambahan melebihkan dari jumlah yang diterima, maka pengembaliannyapun dilarang memberikan penambahan. Tetapi kalau yang berutang atas kemauannya melebihkan jumlah pembayaran itu boleh diterima dan merupakan kebaikan bagi yang berutang.

\section{KESIMPULAN}

Berdasarkan hasil penelitian tentang Praktek Pembayaran Utang Dengan Bekerja Ditinjau Dari Fiqh Muamalah Di Jorong Malintang Nagari Lawang Mandahiling Kecamatan Salimpaung Kabupaten Tanah Datar dapat diambil kesimpulan antara lain:

1. Pelaksanaan pembayaran utang dengan bekerja yang dilakukan oleh masyarakat di Jorong Malintang Nagari Lawang Mandahiling Kecamatan Sallimpaung Kabupaten Tanah Datar, yaitu utang piutang uang yang hanya dilakukan secara lisan tanpa ada bukti tulisan. Apabila jatuh tempo, tapi sipeminjam tidak sanggup untuk membayarnya dan pembayarannya dilakukan dengan bekerja diladang orang tersebut dengan upahnya diambil sebagai ganti utang tersebut.

2. Menurut pandangan fiqh muamalah terhadap pelaksanaan utang dibayar dengan bekerja termasuk kedalam riba, yang mana pihak berpiutang mengambil kelebihan upah uang kerja saat membayar utangnya.

\section{DAFTAR PUSTAKA}

Anwar, S. (2007). Hukum Perjanjian Syariah. Jakarta: Rajawali Press.

Arianti, F. (2014). Fikih Muamalah II. Batusangkar: Stain Batusangkar Press.

Arianti, F. (2015). Fikh Muamalah 1. Batusangkar: Stain Batusangkar

Azharuddin, L. (2005). Fiqh Muamalah. Jakarta: UIN Jakarta Press.

Azzam, A. A. M. (2017). Figh Muamalat Sistem Transaksi Dalam Figh Islam. Jakarta: Amzah. 
Basyir, A. A. (2002). Asas-Asas Hukum Muamalat (Hukum Perdata Islam). Yogyakarta: UII Press.

Djamali. (2002). Hukum Islam Berdasarkan Ketentuan Kurikulum Konsorsium Ilmu Hukum. Bandung: Mandar Maju.

Elimartati. (2010). Hukum Perdata Islam Di Indonesia. Batusangkar: Stain Batusangkar Press. Haroen, N. (2000). Fiqh Muamalah. Jakarta: Gaya Media Pratama.

Harun. (2017). Fiqh Muamalah. Surakarta: Muhammadiyah University Press.

Hasan, M. A. (2004). Berbagai Macam Transaksi Dalam Islam (Fiqh Muamalat). Jakarta: PT Raja Grafindo Persada.

Juhaya. (2014). Figh Muamalah Perbandingan. Bandung: Pustaka Setia.

Lubis, K. S. (2012). Hukum Ekonomi Islam. Jakarta: Sinar grafika.

Mardani. (2013). Hukum Perikatan Syariah Di Indonesia. Jakarta: Sinar Grafika.

Muslich, A. W. (2010). Fiqh Muamalat. Jakarta: Remaja Rosdakarya.

Pasaribu, C. (1996). Hukum Perjanjian Dalam Islam. Jakarta: Sinar Grafika Offset.

Qardhawi, Y. (2011). Halal dan Haram Dalam Islam. Surakarta: Era Adicitra Intermedia.

Rifa'i, M. (1978). Ilmu Figh Islam Lengkap. Semarang: CV. Toba Putra.

Sabiq, S. (2012). Fikih Sunnah 5. Jakarta: Cakrawala Publishing.

Suhendi, H. (2011). Fikih Muamalah: Ekonomi Islam, Hak Milik, Jual Beli, Riba, Musyarakah, Mudayana, Koperasi, Asuransi, Etika Bisnis. Jakarta: PT Raja Grafindo Persada.

Ya'kub, H. (1995). Kode Etik Dagang Menurut Islam. Bandung: Diponegoro. 